\author{
Andrzej Michór \\ Uniwersytet Opolski \\ amichor@uni.opole.pl \\ ORCID: https://orcid.org/0000-0002-4236-0667
}

\title{
Postępowanie zabezpieczające w sprawach gospodarczych
}

\author{
http://dx.doi.org/10.12775/SIT.2021.009
}

\section{Wstęp}

Postępowanie zabezpieczające ma charakter pomocniczy, i to zarówno w stosunku do postępowania rozpoznawczego, jak i egzekucyjnego. W piśmiennictwie trafnie wskazuje się, że zadaniem tego postępowania jest udzielenie natychmiastowej i prowizorycznej, co do zasady, ochrony prawnej określonym podmiotom po to, aby dane postępowanie cywilne, którego przeprowadzenie i ostateczne ukończenie siłą rzeczy wymaga czasu, faktycznie osiągnęło swój zamierzony $\mathrm{cel}^{1}$. Niejednokrotnie jednak postępowanie to wykorzystywane jest przez strony jako element swoistego „testowania” sądu przed wytoczeniem powództwa bądź złożeniem wniosku w postępowaniu nieprocesowym oraz wstępnego badania szans na pozytywne rozstrzygnięcie. $\mathrm{W}$ toku postępowań wniosek o udzielenie zabezpieczenia może też stanowić próbę nacisku na stronę bądź

${ }^{1}$ D. Rystał, w: Kodeks postępowania cywilnego. Tom II. Komentarz do art. 506-1217, red. T. Szanciło, Warszawa 2020, komentarz do art. 730, teza 2. 
uczestnika postępowania mającą na celu skłonienie go do korzystnego dla uprawnionego zawarcia ugody ${ }^{2}$.

Celem niniejszego opracowania jest omówienie wybranych instytucji postępowania zabezpieczającego w kontekście specyfiki spraw gospodarczych w rozumieniu art. $458^{2}$ ustawy $z$ dnia 17 listopada 1964 r. - Kodeks postępowania cywilnego (tekst jednolity: z 2020 r., poz. 1575 ze zm., dalej - k.p.c.). Wnioski o udzielenie zabezpieczenia w tego typu sprawach wpływają do sądów stosunkowo często, zwłaszcza w sprawach o stwierdzenie nieważności uchwały bądź jej uchylenie (wnioski o wstrzymanie wykonania uchwały). W procesach o ustalenie bądź o ukształtowanie stosunku prawnego wnioski te przybierają najczęściej formę żądania unormowania praw i obowiązków stron lub uczestników postępowania na czas jego trwania.

$\mathrm{Z}$ uwagi na ograniczenia redakcyjne $\mathrm{w}$ artykule omówione zostały przesłanki udzielenia zabezpieczenia oraz wybrane aspekty udzielenia zabezpieczenia roszczeń w sprawach gospodarczych o ukształtowanie prawa lub stosunku prawnego albo ustalenie prawa lub stosunku prawnego.

\section{Uprawdopodobnienie roszczenia oraz interesu prawnego}

Zabezpieczenia można domagać się w każdej sprawie cywilnej podlegającej rozpoznaniu przez sąd lub sąd polubowny (art. $730 \S 1$ k.p.c.). Sąd może przy tym udzielić zabezpieczenia przed wszczę-

${ }^{2}$ Zauważyć należy, że sam ustawodawca przewidział pewien „wentyl bezpieczeństwa”, którego celem jest ograniczenie pochopnego składania wniosków o udzielenie zabezpieczenia. Stosownie bowiem do art. $746 \S 1$ k.p.c., jeżeli uprawniony nie wniósł pisma wszczynającego postępowanie $\mathrm{w}$ wyznaczonym terminie albo cofnął pozew lub wniosek, jak również gdy pozew lub wniosek zwrócono albo odrzucono, albo powództwo bądź wniosek oddalono lub postępowanie umorzono, a także w przypadkach wskazanych w art. $744 \S 2$ k.p.c., obowiązanemu przysługuje przeciwko uprawnionemu roszczenie o naprawienie szkody wyrządzonej wykonaniem zabezpieczenia. Roszczenie wygasa, jeżeli nie będzie dochodzone w ciągu roku od dnia jego powstania. Co istotne, odpowiedzialność wynikająca $z$ art. 746 k.p.c. jest odpowiedzialnością za sam wynik 
ciem postępowania lub w jego toku. Natomiast po uzyskaniu przez uprawnionego tytułu wykonawczego dopuszczalne jest udzielenie zabezpieczenia tylko wtedy, jeżeli ma ono na celu zabezpieczenie roszczenia o świadczenie, którego termin spełnienia jeszcze nie nastąpił (art. 730 § 2 k.p.c.).

Stosownie do art. $730^{1} \S 1$ k.p.c. udzielenia zabezpieczenia może żądać każda strona lub uczestnik postępowania, jeżeli uprawdopodobni roszczenie oraz interes prawny w udzieleniu zabezpieczenia. W myśl art. $730^{1} \S 2$ k.p.c. interes prawny w udzieleniu zabezpieczenia istnieje wtedy, gdy brak zabezpieczenia uniemożliwi lub poważnie utrudni wykonanie zapadłego w sprawie orzeczenia lub w inny sposób uniemożliwi lub poważnie utrudni osiągnięcie celu postępowania w sprawie. W piśmiennictwie wskazuje się, że pierwsza $z$ przesłanek tak rozumiany interes prawny wiąże $z$ funkcją konserwacyjną postępowania zabezpieczającego i służy ochronie wierzyciela, który pragnie zagwarantować sobie możliwość zaspokojenia w trybie egzekucyjnym roszczenia dochodzonego przed sądem. Natomiast druga przesłanka udzielenia zabezpieczenia powinna być brana pod uwagę w sprawach, w których orzeczenia kończące postępowanie nie podlegają wykonaniu w trybie egzekucyjnym. Dotyczy to np. szerokiej kategorii procesów o ustalenie i ukształtowanie prawa, których charakter nie zezwala na traktowanie zapadłych w nich orzeczeń sądowych jako tytułów egzekucyjnych, oraz wielu innych spraw, szczególnie $z$ zakresu prawa rodzinnego, które również nie mają takiego przymiotu ${ }^{3}$.

Od dnia 1 stycznia 2020 r. wprowadzona została przy tym nowa regulacja art. $730^{1} \S 2^{1}$ k.p.c. Zgodnie $z$ tym przepisem interes prawny $\mathrm{w}$ udzieleniu zabezpieczenia uważa się za uprawdopo-

procesu i istnieje $z$ mocy szczególnego przepisu, mimo że uprawniony może działać w najlepszej wierze, w sposób zgodny z prawem. Skoda ta musi jednak pozostawać w ścisłym związku przyczynowym z zabezpieczeniem. Zob. E. Stefańska, Odpowiedzialność cywilnoprawna za szkodę wyrządzoną wykonaniem zabezpieczenia, „Transformacje Prawa Prywatnego” 2019, nr 1, s. 82-98.

${ }^{3}$ D. Zawistowski, w: Kodeks postępowania cywilnego. Komentarz. Tom IV. Artykuły 730-1088, red. H. Dolecki, T. Wiśniewski, Warszawa 2014, teza 3 do art. $730^{1}$. 
dobniony, gdy żądającym zabezpieczenia jest powód dochodzący należności zapłaty $\mathrm{z}$ tytułu transakcji handlowej $\mathrm{w}$ rozumieniu ustawy z dnia 8 marca 2013 r. o przeciwdziałaniu nadmiernym opóźnieniom w transakcjach handlowych, w przypadku gdy wartość tej transakcji nie przekracza 75000 zł, a dochodzona należność nie została uregulowana i od dnia upływu terminu jej płatności minęły co najmniej trzy miesiące.

Przy wyborze sposobu zabezpieczenia sąd zobowiązany jest uwzględnić interesy stron lub uczestników postępowania w takiej mierze, aby uprawnionemu zapewnić należytą ochronę prawną, a obowiązanego nie obciążać ponad potrzebę (art. 730 § 3 k.p.c.).

Ustalając, czy w sprawie zachodzi uprawdopodobnienie roszczenia oraz interesu prawnego, należy odwołać się do art. 243 k.p.c. Zgodnie $z$ nim zachowanie szczegółowych przepisów o postępowaniu dowodowym nie jest konieczne, ilekroć ustawa przewiduje uprawdopodobnienie zamiast dowodu. Sąd w postępowaniu zabezpieczającym może odstąpić od zasad postępowania dowodowego oraz reguł przeprowadzania poszczególnych dowodów przewidzianych w przepisach art. 227 i n. k.p.c. Uprawdopodobnienie to niewątpliwie stan mniejszej pewności niż udowodnienie. Oznacza bowiem, że dana okoliczność prawdopodobnie ma miejsce, ale nadal mogą istnieć w tym zakresie pewne wątpliwości. Co istotne, uprawdopodobnienie może zostać przeprowadzone przez sąd za pomocą środków, które uzna on za właściwe, nie wyłączając środków dowodowych ${ }^{4}$.

W piśmiennictwie wskazuje się, że roszczenie obejmuje każde prawo i każdą sytuację prawną podmiotu uprawnionego, w celu ochrony których sąd udzielił mu zabezpieczenia. Roszczenie jest uprawdopodobnione, jeżeli prima facie jest znaczna szansa na jego istnienie, co nie wyklucza tego, że w świetle głębszej analizy stanu faktycznego i prawnego wniosek może okazać się bezzasadny ${ }^{5}$.

${ }^{4}$ Zob. M. Muliński, w: Kodeks postępowania cywilnego. Tom II. Komentarz do art. 730-1217, red. J. Jankowski, Warszawa 2019, komentarz do art. 730¹, teza 5.

${ }^{5}$ E. Stefańska, w: Kodeks postępowania cywilnego. Komentarz. Tom II. Art. 478-1217, red. M. Manowska, Warszawa 2021, komentarz do art. $730^{1}$, teza 7 oraz 10 . 
Jeżeli zabezpieczenie ma nastąpić przed wszczęciem postępowania w sprawie albo w jego początkowym stadium (przed wymianą pism przygotowawczych i pierwszą rozprawą), podstawą ustalenia prawdopodobieństwa istnienia roszczenia będą na ogół twierdzenia wnioskodawcy przytoczone na uzasadnienie wniosku, o ile nie budzą wątpliwości co do zgodności z rzeczywistym stanem (art. 736 $\S 1$ pkt 2$)^{6}$. Natomiast w dalszej fazie postępowania rozpoznawczego oceny, czy roszczenie jest uprawdopodobnione, sąd dokonuje na podstawie całego materiału procesowego będącego w jego dyspozycji ${ }^{7}$.

Uprawniony może przy tym skorzystać ze wszelkich środków, aby przekonać sąd o uprawdopodobnieniu roszczenia i istnieniu po jego stronie interesu prawnego w uzyskaniu zabezpieczenia. Jeżeli zabezpieczenie ma nastąpić przed wszczęciem postępowania w sprawie albo w jego początkowym stadium, podstawą uprawdopodobnienia roszczenia będą twierdzenia wnioskodawcy przytoczone na uzasadnienie wniosku o udzielenie zabezpieczenia, ewentualnie twierdzenia zawarte w piśmie wszczynającym postępowanie rozpoznawcze (pozwie albo wniosku) oraz załączone do tych pism dokumenty ${ }^{8}$. Trafnie wskazuje się przy tym, że dla uprawdopodobnienia roszczenia nie jest jednak wystarczające powołanie się we wniosku o zabezpieczenie jedynie na istniejące dokumenty. Dokumenty te do wniosku należy dołączyć ${ }^{9}$. Wydaje się przy tym, że dopuszczalne byłoby odwołanie się do konkretnych dokumentów znajdujących się w innych aktach (nie do akt - wniosek o dopuszczenie dowodu „Z akt” jest bowiem wadliwy). Sytuacja taka może być uzasadniona wówczas, gdy strona czy uczestnik nie ma dostępu do tych dokumentów, natomiast mają one istotne znaczenie dla uprawdopodobnienia wniosku o udzielenie zabezpieczenia. Uzyskanie takich dokumentów, co do zasady, wydłuży postępowanie w przedmiocie wniosku o udzielenie zabezpieczenia, a w konsekwencji z dużą dozą prawdopodobieństwa nie będzie możliwe jego rozpoznanie

${ }^{6}$ J. Jagieła, w: Kodeks postępowania cywilnego. Tom IV. Komentarz. Art. 730$-1095^{1}$, red. A. Marciniak, Warszawa 2021, komentarz do art. $730^{1}$, teza 3.

${ }^{7}$ M. Muliński, w: Kodeks postępowania, komentarz do art. $730^{1}$, teza 6 .

8 Ibidem.

9 J. Jagieła, w: Kodeks postępowania, komentarz do art. $730^{1}$, teza 3. 
w terminie instrukcyjnym $z$ art. 737 k.p.c. Należy przy tym baczyć, aby uzyskanie takich dokumentów nie naruszało tajemnic prawnie chronionych, np. tajemnicy śledztwa czy tajemnicy bankowej. Uprawniony może bowiem pod pozorem uprawdopodobnienia roszczenia w sposób bezprawny próbować uzyskać dostęp do informacji, których nie powinien otrzymać.

Sąd Apelacyjny w Białymstoku w uzasadnieniu postanowienia z dnia 16 września 2009 r.,trafnie zauważył, że „postępowanie zabezpieczające jest postępowaniem przyśpieszonym i względnie odformalizowanym, w związku $\mathrm{z}$ tym nie wymaga powołania przez wnioskodawcę dowodu $\mathrm{z}$ opinii biegłego w ścisłym rozumieniu przepisów postępowania cywilnego. Dlatego nie można zgodzić się z poglądem, że opinia prywatna sporządzona na zlecenie wnioskodawców nie uprawdopodobnia roszczenia" ${ }^{10}$.

Do problemu uprawdopodobnienia odniósł się również Sąd Apelacyjny $\mathrm{w}$ Krakowie $\mathrm{w}$ uzasadnieniu postanowienia $z$ października 2015 r., I ACz 1675/15 ${ }^{11}$. Sąd stwierdził, że „aby określone zjawisko z określonych dziedzin nauki mogło zostać uznane za wiarygodne w rozumieniu art. $730^{1} \S 1$ k.p.c. bez potrzeby dowodowej weryfikacji tego poglądu opinią biegłego, określona sytuacja, w której stwierdza się brak różnicy między wynalazkiem a rozwiązaniem, któremu zarzuca się naruszenie patentu, winna być widoczna dla osoby o przeciętnej wiedzy i doświadczeniu życiowym, a nie dla specjalisty $z$ określonej dziedziny nauki i wiedzy. W przeciwnym wypadku zasadnicza rola postępowania zabezpieczającego zbliżałaby to postępowanie do postępowania rozpoznawczego, co kłóci się z istotą postępowania zabezpieczającego". Resumując, sąd apelacyjny trafnie podniósł, że postępowanie zabezpieczające nie jest miejscem do rozstrzygania wątpliwości, które wymagają posiadania wiadomości specjalnych. Nie sposób nie zgodzić się także z kolejnym orzeczeniem Sądu Apelacyjnego w Krakowie, który w uzasadnieniu

${ }^{10}$ Postanowienie SA w Białymstoku z dnia 16 września 2009 r., I ACz 739/09, „Orzecznictwo Sądów Gospodarczych” 2010 nr 2, poz. 10, s. 24.

${ }^{11}$ Postanowienie SA w Krakowie $z$ dnia 6 października 2015 r., I ACz 1675/15, Legalis nr 1337981. 
postanowienia z 9 września 2010 r., I ACz 1014/10 12 stwierdził, że „w ramach postępowania o zabezpieczenie - co do zasady - sąd nie czyni stanowczych ustaleń faktycznych, a jedynie ocenia w niezbędnych granicach przedstawiane okoliczności przez pryzmat uprawdopodobnienia faktów istotnych dla zabezpieczenia”.

Na potrzeby zabezpieczenia roszczenie może zostać uprawdopodobnione w jakikolwiek sposób. W orzecznictwie dopuszczono m.in. uprawdopodobnienie za pomocą kserokopii, jeżeli przedstawione przez uprawionego dokumenty w postaci kserokopii nie budziły wątpliwości co do ich rzetelności ${ }^{13}$. Na uprawdopodobnienie okoliczności może wskazywać także artykuł w prasie ${ }^{14}$.

Sąd Apelacyjny we Wrocławiu w uzasadnieniu postanowienia z 30 stycznia 2012 r., I ACz 67/12 ${ }^{15}$ podniósł, że „przyjmuje się, że roszczenie jest uprawdopodobnione, jeżeli prima facie istnieje znaczna szansa jego istnienia. Wymóg uprawdopodobnienia roszczenia wiąże się z koniecznością uprawdopodobnienia faktów, z których jest ono wywodzone. Należy przy tym zaznaczyć, iż uprawdopodobnienie nie przesądza udowodnienia mogącego być podstawą do pozytywnego rozstrzygnięcia co do meritum sprawy. Istotą postępowania zabezpieczającego jest bowiem to, że sąd dokonuje jedynie pobieżnej (wstępnej) analizy dostarczonego przez wnioskodawcę

12 Postanowienie SA w Krakowie z dnia 9 września 2010 r., I ACz 1014/10, Legalis nr 298077.

13 Zob. uzasadnienie postanowienia SA w Gdańsku z 29 września 2015 r., I ACz 707/15, Legalis nr 1337978. Dość ciekawą tezę sformułował Sąd Apelacyjny w Katowicach w uzasadnieniu postanowienia z 19 lutego 2013 r., I ACz 124/13, Legalis nr 1025023. Stwierdził, że „dla uznania, że roszczenie jest wiarygodne, wystarczające było przedłożenie przez powoda kopii sygnowanych nazwiskiem i imieniem pozwanego oświadczeń, z których wynika, że egzekwowana przez niego wierzytelność została zaspokojona. Okoliczność, że obecnie pozwany kwestionuje autentyczność owych dokumentów, nie pozbawia roszczenia powoda prawdopodobieństwa, skutek taki bowiem odnieść by mogło dopiero przedstawienie dowodu autentyczność tę podważającego, na przykład dopuszczonej w toczącym się postępowaniu przygotowawczym”.

${ }^{14}$ Zob. uzasadnienie postanowienia SA we Wrocławiu z 30 stycznia 2012 r., I ACz 67/12, Legalis nr 732885.

15 Postanowienie SA we Wrocławiu z dnia 30 stycznia 2012 r., I ACz 67/12, Legalis nr 732885. 
materiału dowodowego”. W konsekwencji „roszczenie jest uprawdopodobnione, jeżeli na pierwszy rzut oka, tj. bez głębszego wnikania we wszystkie możliwe aspekty faktyczne i prawne sprawy, istnieje szansa - w świetle przytoczonych przez wnioskodawcę twierdzeń faktycznych, popartych dowodami lub środkami niebędącymi dowodami w rozumieniu kodeksu postępowania cywilnego że przysługuje ono uprawnionemu". Skutkuje to zatem brakiem konieczności przedstawienia niepodważalnych dowodów ${ }^{16}$. W fazie rozpoznawania wniosku o udzielenie zabezpieczenia wystarczające jest zatem przeprowadzenie wstępnej analizy zaoferowanego materiału dowodowego, tj. wysnucie wniosku, czy na podstawie dowodów zaoferowanych przez uprawnionego można postawić tezę o przysługującym mu roszczeniu wobec obowiązanego ${ }^{17}$.

W tym miejscu należy rozważyć, czy w ramach postępowania o udzielenie zabezpieczenia sąd uprawniony jest do weryfikowania twierdzeń uprawnionego przez konfrontowanie ich $z$ dowodami, które nie zostały przez niego zaoferowane na etapie składania wniosku, innymi słowy: czy sąd może poszukiwać w tym postępowaniu dowodów $z$ urzędu. W piśmiennictwie trafnie zauważono, że w postępowaniu zabezpieczającym nie jest wyłączona możliwość prowadzenia postępowania dowodowego, jednakże $z$ uwagi na jego cel polegający na udzieleniu uprawnionemu natychmiastowej ochrony należy dążyć do jak najszybszego wydania rozstrzygnięcia w przedmiocie wniosku ${ }^{18}$. Wydaje się, że nie można wykluczyć takiej sytuacji, zwłaszcza wówczas, gdy uprawniony i obowiązany oraz ich sytuacja prawna bądź faktyczna są znane sądowi $z$ urzędu $z$ innych spraw. Wielokrotnie bowiem, zwłaszcza w sprawach o uchylenie uchwały lub stwierdzenie jej nieważności, strony składają wiele pozwów, procesy mają zaś charakter kaskadowy i związane są z innymi sporami i sprawami zawisającymi przez sądami. Tymczasem $\mathrm{w}$ postępowaniu zabezpieczającym niejednokrotnie uprawnieni,

16 Zob. uzasadnienie postanowienia SA w Krakowie z 15 czerwca 2015 r., I ACz 1036/15, Legalis nr 1285418.

17 Postanowienie SA w Gdańsku z 14 listopada 2013 r., I ACz 1162/13, Legalis nr 746935.

${ }^{18}$ E. Stefańska, w: Kodeks postępowania, komentarz do art. 730 ${ }^{1}$, teza 11. 
składając wniosek o udzielenie zabezpieczenia, opierają go na selektywnie wybranych dowodach, pomijając niewygodne dla siebie fakty.

Uprawdopodobnienie interesu prawnego zachodzi wówczas, gdy brak zabezpieczenia uniemożliwi lub poważnie utrudni wykonanie zapadłego w sprawie orzeczenia lub w inny sposób uniemożliwi lub poważnie utrudni osiągnięcie celu postępowania w sprawie. Ustawodawca wprowadził przy tym szczególne unormowanie w art. 730 ${ }^{1}$ $\S 2^{1}$ k.p.c. Zgodnie bowiem $\mathrm{z}$ nim w przypadku gdy wartość transakcji handlowej nie przekracza 75000 zł, a dochodzona należność nie zostanie uregulowana i od dnia upływu terminu jej płatności upłynęły co najmniej trzy miesiące, to interes prawny uważa się za uprawdopodobniony, jeżeli zabezpieczenia żąda powód dochodzący „należności zapłaty”19. Poza tą szczególną sytuacją uprawdopodobnienie zachodzi wówczas, gdy istnieje potrzeba udzielenia należytej ochrony prawnej, tj. usunięcia naruszenia albo zagrożenia naruszenia praw uprawnionego. W piśmiennictwie wskazuje się, $\dot{z ̇ e}$ „nie istnieje zatem interes prawny w udzieleniu zabezpieczenia tam, gdzie naruszenie lub zagrożenie naruszenia praw uczestników nie występuje, chociaż sprawa nie jest jeszcze definitywnie załatwiona, albo wprawdzie do naruszenia już doszło, ale nie zachodzi potrzeba jego usunięcia przed zakończeniem postępowania, gdyż mimo to realizacja praw uprawnionego (w przyszłości) nie jest w żaden sposób zagrożona, np. gdy obowiązany nie spełnił świadczenia, lecz z uwagi na jego sytuację majątkową oraz zachowanie nie istnieje zagrożenie wykonania orzeczenia, którym to świad-

19 A. Jakubecki wskazuje, że powód dochodzący należności z tytułu transakcji handlowej, żądając zabezpieczenia swego roszczenia, powinien zatem uprawdopodobnić jego istnienie, nie musi zaś uprawdopodobniać interesu prawnego w uzyskaniu zabezpieczenia. Zamiast tego wykazać powinien, że należność nie została uregulowana przez pozwanego, od dnia upływu terminu jej płatności upłynęły co najmniej trzy miesiące oraz że jej wysokość nie przekracza 75000 zł. Autor trafnie przy tym podkreśla, że jest to kwota, na którą opiewa transakcja handlowa, a nie wartość przedmiotu sporu. W konsekwencji jeżeli powód dochodzi w procesie tylko części swej należności w wysokości niższej niż 75000 zł, to art. $7301 \S 21$ nie znajduje zastosowania. A. Jakubecki, w: Kodeks postępowania cywilnego. Komentarz do wybranych przepisów nowelizacji 2019, red. A. Jakubecki, Warszawa 2019, komentarz do art. $730^{1}$, teza 8. 
czenie zostanie zasądzone" ${ }^{20}$. Inaczej rzecz ujmując: o uprawdopodobnieniu interesu prawnego mówimy wówczas, gdy w sprawie zachodzą takie okoliczności faktyczne lub prawne, których rozsądna ocena prowadzi do wniosku, że wydane w danej sprawie orzeczenie merytoryczne w postępowaniu rozpoznawczym nie wystarczy do udzielenia określonej osobie skutecznej ochrony prawnej ${ }^{21}$.

W odniesieniu do roszczeń pieniężnych na potrzebę udzielenia zabezpieczenia wskazują m.in. następujące okoliczności: przeciwko dłużnikowi toczą się liczne postępowania rozpoznawcze i egzekucyjne, ma on zamiar sprzedać swój majątek i wyjechać za granicę, popadł w zwłokę ze spłatą udzielonych mu kredytów albo pożyczek, zamierza zaprzestać (lub zaprzestał) prowadzenia działalności gospodarczej, jako przedsiębiorca zalega $z$ wypłatą należnych pracownikom wynagrodzeń albo z zapłatą należności publicznoprawnych, grozi mu upadłość czy też miejsce jego pobytu nie jest znane. Natomiast w odniesieniu do roszczeń niepieniężnych jako przesłanki udzielenia zabezpieczenia wskazuje się np. takie: zachowanie obowiązanego zmierza do naruszenia dóbr osobistych lub praw majątkowych, których dotyczy postępowanie ${ }^{22}$, może także wynikać $z$ obawy zniszczenia lub ukrycia rzeczy, której wydania żąda powód, zniszczenia lub wyzbycia się przedmiotów, w stosunku do których obowiązany ma podjąć czynności (np. usunięcie bezprawnie umieszczonych znaków towarowych) ${ }^{23}$. Co istotne, podstawą zabezpieczenia roszczeń nie może być jednak subiektywna obawa wnioskodawców, że strona pozwana w toku procesu doprowadzi do wyzbycia się majątku².

${ }^{20}$ J. Jagieła, w: Kodeks postępowania, komentarz do art. $730^{1}$, teza 5 .

${ }^{21}$ M. Muliński, w: Kodeks postępowania, komentarz do art. $730^{1}$, teza 7.

22 Ibidem.

23 A. Jakubecki, w: Kodeks postępowania, komentarz do art. $730^{1}$, teza 4 .

${ }^{24}$ Zob. postanowienie SA w Szczecinie z dnia 17 września 2018 r., III APz 9/18, Legalis nr 1852279. W orzecznictwie trafnie wskazuje się, że sam fakt nieregulowania zobowiązania przez dłużnika dochodzonego w sprawie roszczenia pieniężnego oraz istnienie zobowiązań wobec innych wierzycieli ujawnionych nie stwarza jeszcze groźby, o której mowa w art. $730^{1} \S 2$ k.p.c., jeżeli nie jest połączony $z$ analizą ogólnej sytuacji majątkowej dłużnika i podejmowanych przez niego działań zmierzających np. do wyzbycia się poszczególnych składników 
W postępowaniu w sprawach gospodarczych stosunkowo często wnioski o udzielenie zabezpieczenia uzasadniane są koniecznością tymczasowego uregulowania sposobu reprezentowania spółki prawa handlowego bądź zawieszenia obowiązywania uchwał zgromadzenia w spółce dotyczących innych jej istotnych spraw. Jak wskazano wyżej, w przedmiotowym postępowaniu sąd dokonuje jedynie pobieżnej (wstępnej) analizy dostarczonego przez wnioskodawcę materiału dowodowego. Założenie to, chociaż zasadne, wymaga jednak pewnego wyjaśnienia. Owa „pobieżność” analizy nie może wszakże oznaczać dowolności czy braku rozwagi w udzielaniu zabezpieczenia, tym bardziej że często wywołuje ono doniosłe konsekwencje dla obowiązanego oraz uprawnionego. W piśmiennictwie trafnie zauważa się, że wydając zarządzenie tymczasowe, sąd musi mieć zawsze w sposób szczególny na uwadze skutki prawne, jakie orzeczenie to spowoduje: $\mathrm{w}$ jakim zakresie $\mathrm{z}$ powodu zabezpieczenia roszczenia zmieni się sytuacja prawna obowiązanego i uprawnionego, jak też czy cel zabezpieczenia roszczenia zostanie osiągnięty ${ }^{25}$.

W tym miejscu należy zauważyć, że uprawdopodobnienie dotyczy zarówno okoliczności faktycznych, na których wnioskodawca opiera swoje roszczenie, jak i podstawy prawnej roszczenia, która powinna być również prawdopodobna w tym znaczeniu, że dochodzone roszczenie znajduje swoją podstawę normatywną ${ }^{26}$. Inaczej rzecz ujmując - konieczne jest dokonanie jego wstępnej oceny z punktu widzenia wchodzących $\mathrm{w}$ grę przepisów prawa materialnego. W konsekwencji nie będzie można uznać roszczenia za prawdopodobne, jeżeli, w świetle niebudzących wątpliwości przepisów prawa, przewidywać należy, racjonalnie oceniając stan rzeczy, że roszczenie to $\mathrm{w}$ procesie nie zostanie uwzględnione ${ }^{27}$.

tego majątku. Zob. postanowienie SO w Toruniu z dnia 28 czerwca 2017 r., VI Gz 142/17, Legalis nr 1829276.

${ }^{25}$ M. Lewandowski, Glosa do orzeczenia SN z dnia 24 lutego 1999 r., III CKN 182/98, „Problemy Egzekucji” 2000, nr 4, s. 94 i n.

${ }^{26}$ Zob. postanowienie SA we Wrocławiu z 31 grudnia 2013 r., I ACz 2541/13, Legalis nr 776105.

27 Zob. postanowienie SA w Poznaniu z 16.01.2013., I ACz 2173/12, Legalis nr 30571. 
Oddalenie wniosku o udzielenie zabezpieczenia nie statuuje powagi rzeczy osądzonej. Jak trafnie zauważył Sąd Apelacyjny w Gdańsku w uzasadnieniu postanowienia z 29 września 2015 r., I ACz $707 / 15^{28}$, „tak jak nie ma podstaw do przyjęcia, że prawomocne postanowienie sądu w przedmiocie zabezpieczenia wywołuje stan rzeczy osądzonej (res iudicata), podobnie nie ma podstawy prawnej do odrzucenia kolejnego wniosku o udzielenie zabezpieczenia, nawet opartego na tych samych okolicznościach, $\mathrm{z}$ uwagi na zawisłość sporu (lis pendens)". W praktyce sytuacje takie zdarzają się na etapie przedprocesowym. Bywa, że uprawnieni usiłują bowiem „trafić” na sędziego, który będzie skłonny do uwzględnienia ich roszczeń, bądź wnioski takie składają do różnych sądów w sytuacjach, gdy mają możliwość wyboru właściwego sądu. Stanowi to również element taktyki „testowania” sądu celem ustalenia, jakie szanse na uwzględnienie ma ich roszczenie. Aby wyeliminować takie praktyki zmieniono przepisy ustawy z dnia 28 lipca 2005 r. o kosztach sądowych w sprawach cywilnych ${ }^{29}$. Zgodnie bowiem $\mathrm{z}$ zawartym tam art. 69 ust. 1 od wniosku o udzielenie zabezpieczenia roszczenia pieniężnego złożonego przed wniesieniem pisma wszczynającego postępowanie pobiera się czwartą część opłaty należnej od pozwu o to roszczenie. W myśl art. 69 ust. 2 uiszczoną opłatę zalicza się na poczet opłaty od pisma wszczynającego postępowanie, jeżeli zostało wniesione $\mathrm{w}$ terminie przewidzianym do tego $\mathrm{w}$ przepisach o zabezpieczeniu. W przypadku oddalenia wniosku termin ten wynosi dwa tygodnie od dnia doręczenia postanowienia, a jeżeli postanowienie zostało wydane na posiedzeniu jawnym - od dnia jego ogłoszenia. Nadal jednak pozostawiono stosunkowo niską opłatę od wniosków o udzielenie zabezpieczenia roszczeń niepieniężnych (100 zł - art. 68 pkt 1 u.k.s.s.c.).

${ }^{28}$ Postanowienie SA w Gdańsku z dnia 29 września 2015 r., I ACz 707/15, Legalis nr 1337978.

${ }^{29}$ Tekst jednolity: Dz.U. z 2020 r. poz. 755 ze zm., dalej - u.k.s.s.c. 


\section{Udzielenie zabezpieczenia w sprawach o ukształtowanie prawa lub stosunku prawnego albo ustalenie prawa lub stosunku prawnego}

W piśmiennictwie podnosi się, że w przypadkach gdy żądana ochrona prawna polega na ukształtowaniu prawa lub stosunku prawnego albo ustaleniu prawa lub stosunku prawnego, chodzi zazwyczaj o wyeliminowanie sytuacji, w których ochrona zapewniana przez orzeczenie sądu przychodzi zbyt późno, w wyniku czego udaremnione zostają jej skutki. W konsekwencji celem zabezpieczenia jest wówczas zapewnienie skuteczności przyszłego orzeczenia. Andrzej Jakubecki wskazał, że przez pojęcie skuteczności rozumie się różnego rodzaju skutki orzeczenia, zarówno te wynikające $z$ jego treści (np. orzeczenie jako podstawa wpisu do rejestru), jak i uboczne, a zabezpieczenie może dotyczyć obu kategorii skutków ${ }^{30}$.

W sprawach gospodarczych wnioski o udzielenie zabezpieczenia w powyższej kategorii dotyczą głównie spraw o rozwiązanie spółki, stwierdzenie nieważności uchwały bądź jej uchylenie. Treść żądań wniosków o udzielenie zabezpieczenia jest przy tym różna. Do typowych należy żądanie wstrzymania wykonania czy skuteczności uchwały, jak też żądanie zawieszenia postępowania rejestrowego dotyczącego zmian w rejestrze przedsiębiorców. Sporadycznie pojawiają się jednak innego typu wnioski, np. o zajęcie konta bankowego i ruchomości należących do spółki. W sprawach o stwierdzenie nieważności uchwały bądź jej uchylenie wnioski o udzielenie zabezpieczenia występują niemal we wszystkich sprawach, co wynika ze specyfiki tych postępowań. Nierzadko spory między stronami występują kaskadowo, bądź gdy zaskarżany jest ciąg kilku następujących po sobie uchwał z tej samej daty, bądź gdy spór sądowy stanowi kolejną odsłonę konfliktu wspólników.

${ }^{30}$ A. Jakubecki, w: Kodeks postępowania, komentarz do art. $730^{1}$, teza 6 . 
Niewątpliwie przedmiotem zabezpieczenia mogą być procesowe roszczenia o uchylenie uchwały wspólników spółki z ograniczoną odpowiedzialnością (art. 249-251 ustawy z dnia 15 września 2000 r. Kodeks spółek handlowych, t.j.: Dz.U. z 2020 r., poz. 1526 ze zm., dalej - k.s.h.) oraz o stwierdzenie nieważności uchwały wspólników spółki z ograniczoną odpowiedzialnością (art. 252 k.s.h.) ${ }^{31}$. Analogicznie rzecz się ma $z$ uchwałami uchwały walnego zgromadzenia w spółce akcyjnej (zob. art. 422 oraz art. 425 k.s.h.). Natomiast wątpliwości wywołuje możliwość zabezpieczenia roszczenia o stwierdzenie nieważności uchwały wspólników spółki z ograniczoną odpowiedzialnością przez zawieszenie postępowania rejestrowego dotyczącego wpisu zmian w składzie organów spółki. Za jej dopuszczalnością opowiedział się Sąd Najwyższy w uchwale z dnia 21 lipca 2010 r., III CZP 49/1032. Odmienne stanowisko SN zajął w uchwale $z$ dnia 17 grudnia 2015 r., III CZP 91/15. Zauważył, że

${ }^{31}$ Por. uzasadnienie uchwały składu siedmiu sędziów SN z dnia 18 września 2013 r., III CZP 13/13, „Orzecznictwo Sądu Najwyższego Izba Cywilna” 2014, nr 3, poz. 23; uzasadnienie uchwały SN z dnia 17 grudnia 2015 r., III CZP 91/15, „Orzecznictwo Sądu Najwyższego Izba Cywilna” 2017 nr 1, poz. 6, Legalis nr 1361751. Zob. także M. Dumkiewicz, A. Kidyba, Wybrane problemy związane ze skutkami zaskarżania uchwał zgromadzeń spółek kapitałowych $w$ przedmiocie podziału zysku, „Przegląd Prawa Handlowego” 2013, nr 11 , s. $11 \mathrm{i} \mathrm{n.}$

${ }^{32}$ Uchwała SN z dnia 21 lipca 2010 r., III CZP 49/10, „Orzecznictwo Sądu Najwyższego Izba Cywilna” 2011, nr 1, poz. 7. SN w uzasadnieniu tej uchwały stwierdził, że w przykładowym katalogu sposobów zabezpieczenia roszczeń niepieniężnych, zawartym w art. 755 k.p.c., nie jest wymienione zawieszenie postępowania rejestrowego. Zauważył jednak, że w pkt 3 tego przepisu wymienia się zawieszenie egzekucji lub postępowania wykonawczego. W konkluzji stwierdził, że brak bliższego określenia, co oznacza „postępowanie wykonawcze” w rozumieniu tego przepisu, prowadzi do przyjęcia, że chodzi tu o każde postępowanie zmierzające do wykonania orzeczenia lub decyzji, których istnienie, ważność lub skuteczność są przedmiotem postępowania w sprawie, w której udzielone zostało zabezpieczenie. Podniósł, że sposobem wykonania uchwały wspólników spółki z ograniczoną odpowiedzialnością powodującej zmianę danych podlegających wpisowi do rejestru (np. nazwisk i imion członków rady nadzorczej - art. $168 \mathrm{w}$ związku z art. 166 § 1 pkt 6 k.s.h.) lub kreującej zdarzenia podlegające takiemu wpisowi jest wpisanie tych zmian lub zdarzeń do rejestru. Analogiczne stanowisko zajął SA we Wrocławiu w uzasadnieniu 
jakkolwiek art. $755 \S 1$ k.p.c. dopuszcza zabezpieczenie procesowego roszczenia niepieniężnego w każdy sposób adekwatny w danych okolicznościach do treści tego roszczenia, to jednak brak kompetencji innego sądu niż prowadzący postępowanie rejestrowe do zawieszenia postępowania rejestrowego. Cel przyświecający temu rozstrzygnięciu można przy tym osiągnąć w inny sposób - przez udzielenie zabezpieczenia polegającego na wstrzymaniu skuteczności zaskarżonych uchwał. Sąd Najwyższy trafnie przy tym wskazał, że „chodzi tu $\mathrm{w}$ istocie nie o wstrzymanie wykonalności zaskarżonych uchwał, lecz o wstrzymanie ich skuteczności" ${ }^{33}$. Powyższe uwagi należy odnieść także do uchwał walnego zgromadzenia w spółce akcyjnej.

Postępowanie o udzielenie zabezpieczenia we wspomnianych wyżej typach spraw może stanowić próbę uzyskania wstępnego stanowiska sądu na temat zasadności roszczenia. Nie sposób nie zauważyć, że przesłanki do uchylenia uchwał oparte są m.in. na klau-

postanowienia $z$ dnia 19 stycznia 2012 r., I ACz 45/12, Legalis nr 732879 oraz SA w Poznaniu w uzasadnieniu postanowienia $z$ dnia 12 lutego $2013 \mathrm{r}$. I ACz 2175/12, Legalis nr 730572. A. Owczarewicz, dopuszczając możliwość takiego sposobu udzielenia zabezpieczenia, wskazuje, że o ile w ogóle jest możliwe, zabezpieczenie postępowania o uchylenie uchwały przez zawieszenie postępowania rejestrowego może być zastosowane tylko do momentu dokonania wpisu przez sąd rejestrowy. Po tej chwili tego rodzaju sposób zabezpieczenia nie będzie odpowiedni w rozumieniu art. $755 \S 1$ k.p.c. A. Owczarewicz, Zabezpieczenie powództwa o uchylenie bądź stwierdzenie nieważności uchwat organów właścicielskich spółek kapitałowych przez zawieszenie postępowania rejestrowego po nowelizacji Kodeksu postępowania cywilnego, „Prawo Spółek” 2012, nr 11-12, s. 138 i n.

${ }^{33}$ SN stwierdził przy tym, że „osoba odwołana $z$ zarządu przez czas trwania zabezpieczenia będzie mieć nadal status członka zarządu, a osoba powołana nie uzyska w tym czasie tego statusu, $z$ wszystkimi tego konsekwencjami w zakresie związanym z prowadzeniem spraw spółki i reprezentacji spółki. Postanowienie o udzieleniu omawianego zabezpieczenia zaopatrzone we wzmiankę o wykonalności (art. 743 § 2 k.p.c.) stanowi zarazem przeszkodę do dokonania wpisu uchwalonej zmiany w składzie zarządu w rejestrze. Choć bowiem wpis zmiany do rejestru ma jedynie charakter deklaratoryjny (por. wyrok Sądu Najwyższego z dnia 25 września 2003 r., V CK 198/02), to jednak jest wymagany przez ustawę (art. 168 k.s.h.) i ma duże znaczenie dla bezpieczeństwa obrotu prawnego. Omawiane zabezpieczenie sprawia, że przez czas jego trwania zaskarżona uchwała nie może stanowić podstawy wpisu uchwalonej zmiany do rejestru". 
zuli generalnej dobrych obyczajów. Uchwała wspólników w spółce z o.o. oraz walnego zgromadzenia w spółce akcyjnej może być bowiem stosownie do art. $249 \S 1$ oraz art. $422 \S 1$ k.s.h. skarżona do sądu $z$ uwagi na fakt, że jest sprzeczna $z$ umową spółki (spółka z o.o.) lub statutem (spółka akcyjna) bądź dobrymi obyczajami i godzi w interesy spółki lub ma na celu pokrzywdzenie wspólnika (spółka $z$ o.o.) lub akcjonariusza (spółka akcyjna). W piśmiennictwie sporne jest to, czy przesłanka sprzeczności $z$ umową spółki lub statutem ma charakter samodzielny ${ }^{34}$. Bez wątpienia natomiast sprzeczność $z$ dobrymi obyczajami może stanowić podstawę uchylenia, jeżeli jednocześnie godzi w interesy spółki lub ma na celu pokrzywdzenie wspólnika lub akcjonariusza ${ }^{35}$.

Należy zauważyć, że pojęcie dobrych obyczajów odnosi się nie tylko do uczciwości kupieckiej skierowanej na zewnątrz funkcjonowania spółki (w stosunku do innych uczestników obrotu gospodarczego), ale przede wszystkim do stosunków wewnętrznych w spółce, w tym relacji pomiędzy wspólnikami. Kodeks spółek handlowych nie zawęża pojęcia dobrych obyczajów do norm uczciwości panujących pomiędzy przedsiębiorcami ${ }^{36}$. Oznacza to konieczność sięgnięcia do kryteriów moralnych obowiązujących nie tylko pomiędzy przedsiębiorcami, ale także panujących w społeczeństwie, w tym ogólnej normy przyzwoitego zachowania ${ }^{37}$. Oparcie wniosku o udzielenie zabezpieczenia na naruszeniu klauzuli generalnej przekłada się na trudności w orzekaniu w postępowaniu zabezpieczającym, związane z koniecznością wyważenia tego, czy istotnie w sprawie uprawdopodobniono roszczenie. Jest to przy tym dość trudne $z$ uwagi na

34 Por. A. Rachwał, w: Prawo spółek handlowych. System Prawa Handlowego. Tom 2A, red. A. Szumański, Warszawa 2019, teza 12.8.1.3. do art. 249; R. Pabis, w: Kodeks spółek handlowych. Komentarz, red. J. Bieniak Warszawa 2020, komentarz do art. 249, teza III.2; T. Regucki, Czy sprzeczność ze statutem albo umowa spótki może być samodzielna podstawa powództwa o uchylenie uchwały?, „Przegląd Prawa Handlowego” 2014, nr 10, s. 20-24.

35 A. Rachwał, w: Prawo spótek, komentarz do art. 249, teza 12.8.1.3.

${ }^{36}$ Zob. uzasadnienie wyroku SA w Katowicach z dnia 26 marca 2009 r., V ACa 49/09, „Orzecznictwo Sądów Apelacyjnych” 2010, nr 7, poz. 19.

${ }^{37}$ M. Chomiuk, w: Kodeks spółek handlowych. Komentarz, red. Z. Jara, Warszawa 2020, komentarz do art. 249, teza II.B.b.2. 
rozstrzyganie sprawy bez zapoznania się ze stanowiskiem drugiej strony, która najczęściej odniesie się do wniosku o udzielenie zabezpieczenia w zażaleniu poziomym do innego składu sądu okręgowego rozpoznającego sprawę. $Z$ uwagi na powyższe zmiany postanowień pierwszoinstancyjnych $\mathrm{w}$ toku instancji nie należą do rzadkości i często wynikają $z$ analizy materiału dowodowego złożonego przez obowiązanego.

Sąd Apelacyjny w Poznaniu w uzasadnieniu postanowienia $z$ dnia 12 lutego 2013 r., I ACz 2175/12 $2^{38}$ trafnie stwierdził, że „Z mocy art. 249 § 1 k.s.h. do obowiązków sądu należy ocena, czy zaskarżone uchwały nie godzą w interesy spółki lub nie mają na celu pokrzywdzenia wspólnika, w tym także $z$ punktu widzenia ekonomicznego". Ocena ta musi być zatem kompleksowa i nie może charakteryzować się dowolnością, tym bardziej że skutki udzielenia bądź odmowy udzielenia zabezpieczenia są daleko idące.

W orzecznictwie można wskazać na kilka ciekawych problemów wprost związanych z zaskarżaniem uchwał bądź domaganiem się stwierdzenia ich nieważności. Sąd Apelacyjny w Krakowie w uzasadnieniu postanowienia $z$ dnia 8 grudnia 2016 r., I ACz 2166/1639 wskazał, że skoro zaskarżone uchwały przez podwyższenie kapitału zakładowego spółki, emisję nowych akcji (warrantów) z pozbawieniem prawa poboru dotychczasowych akcjonariuszy stwarzają niebezpieczeństwo uczynienia $z$ akcjonariusza większościowego, jakim jest wnioskodawca (posiadającego ok. 1/3 pakietu akcji), akcjonariusza mniejszościowego, zmarginalizowania jego pozycji w spółce, to brak zabezpieczenia w sprawie mógłby doprowadzić do daleko idących skutków, których odwrócenie byłoby trudne oraz zagrażałoby interesom osób trzecich, działających w dobrej wierze. Sąd Apelacyjny w Poznaniu w uzasadnieniu postanowienia $z$ dnia 17 stycznia 2013 r., I ACz 81/13 ${ }^{40}$ stwierdził, że możliwe jest ustano-

38 Postanowienie SA w Poznaniu z dnia 12 lutego 2013 r., I ACz 2175/12, Legalis nr 730572 .

39 Postanowienie SA w Krakowie $z$ dnia 8 grudnia 2016 r., I ACz 2166/16, Legalis nr 1558606.

40 Postanowienie SA w Poznaniu z dnia 17 stycznia 2013 r., I ACz 81/13, Legalis nr 740247. 
wienie zabezpieczenia roszczenia o ustalenie nieważności czynności prawnej - umowy sprzedaży udziałów w spółce kapitałowej - przez zakazanie zbycia lub obciążenia tych udziałów.

Sąd Apelacyjny w Warszawie w uzasadnieniu wyroku $\mathrm{z}$ dnia 3 października 2012 r., I ACa 265/12 $2^{41}$ podniósł, że zabezpieczenie powództwa o wyłączenie wspólnika na podstawie art. 268 k.s.h. może polegać na jego zawieszeniu w wykonywaniu wszystkich lub tylko niektórych praw udziałowych w spółce. W tym miejscu należy zauważyć, że o zakresie udzielonego zabezpieczenia decyduje ostatecznie sąd, opierając się na okolicznościach konkretnego przypadku, przy czym trzeba też mieć na względzie fakt, że sąd związany jest granicami wniosku o udzielenie zabezpieczenia (art. 738 k.p.c.). Sąd może zatem uwzględnić wniosek o udzielenie zabezpieczenia w części - ale w granicach wniosku.

W tym miejscu należy zauważyć, że w postępowaniu o udzielenie zabezpieczenia, którego przedmiotem jest roszczenie osoby odwołanej $\mathrm{z}$ zarządu o uchylenie lub stwierdzenie nieważności uchwał zgromadzenia wspólników o zmianach w składzie zarządu, spółki z ograniczoną odpowiedzialnością nie może reprezentować zarząd spółki. W takim przypadku ma zastosowanie art. $253 \S 2$ k.s.h. ${ }^{42}$ Zgodnie z tym przepisem, jeżeli zarząd nie może działać za spółkę, a brak uchwały wspólników o ustanowieniu pełnomocnika, sąd właściwy do rozstrzygnięcia powództwa wyznacza kuratora spółki.

Sąd Najwyższy w uchwale $z$ dnia 9 października 1991 r., III CZP 93/91 ${ }^{43}$ wskazał, że „nie jest dopuszczalne zabezpieczenie żądania wspólnika rozwiązania spółki z ograniczoną odpowiedzialnością (art. 263 pkt 1 Kodeksu handlowego) przez zajęcie konta bankowego i ruchomości należących do tej spółki” ${ }^{44}$. Orzeczenie

${ }^{41}$ Wyrok SA w Warszawie $z$ dnia 3 października 2012 r., I ACa 265/12, Legalis nr 730819.

${ }^{42}$ Zob. uchwała SN z dnia 17 grudnia 2015 r., III CZP 91/15.

${ }^{43}$ Uchwała SN z dnia 9 października 1991 r., III CZP 93/91, Lex nr 5344.

${ }^{44} \mathrm{SN}$ w cyt. uchwale $z$ dnia 9 października 1991 r., III CZP 93/91 stwierdził, że „wniosek o zabezpieczenie żądania rozwiązania spółki może wynikać z obawy wspólnika, iż zła działalność doprowadzi w spółce do sytuacji kryzysowej z punktu widzenia tego, co wspólnik uważa za słuszne dla jego majątkowego 
to spotkało się z krytycznym przyjęciem w doktrynie. Józef Frąckowiak zauważył, że odmawiając możliwości wydania zarządzenia tymczasowego, w trybie art. 730 k.p.c., w istocie Sąd Najwyższy godzi się na działania prezesa zarządu i głównego wspólnika ewidentnie szkodliwe dla spółki i pozostałych wspólników. Stwierdził, że wskazane w uzasadnieniu glosowanej uchwały postanowienia kodeksu handlowego niczego wspólnikom pozostającym w mniejszości nie gwarantują - niczego, co pozwoliłoby na skuteczne i szybkie wyeliminowanie możliwości wyzbywania się przez spółkę jej majątku ${ }^{45}$. Jak wskazuje Andrzej Jakubecki, „powstanie roszczenia o wypłatę udziału w sumie likwidacyjnej jako konsekwencja rozwiązania spółki $z$ ograniczoną odpowiedzialnością należy bowiem uważać za uboczny skutek wyroku rozwiązującego spółkę, który to skutek podlega zabezpieczeniu w postępowaniu zabezpieczającym” ${ }^{46}$. Tadeusz Ereciński trafnie zauważył, że „przez skuteczność orzeczenia należy bowiem rozumieć zarówno skutki wynikające $z$ treści orzeczenia (orzeczenie jako podstawa wpisu do rejestru), jak i skutki uboczne" 47 .

W Kodeksie spółek handlowych ustanowiono przepis szczególny odnoszący się do udzielenia zabezpieczenia w sprawach o wyłączenie wspólnika w spółce z o.o. oraz - od dnia 1 lipca 2021 r., na mocy art. $300^{49} \S 2$ k.s.h., do akcjonariusza w prostej spółce

interesu. Jest to jednak kwestia, która wykracza poza cel procesu o rozwiązanie spółki. Wprawdzie w zasięgu przedmiotu tego procesu pozostaje określona ważna przyczyna, która według powoda czyni niemożliwym utrzymanie spółki, to jednak - co również słusznie zauważył sąd apelacyjny - w sytuacji zagrożenia interesu spółki wspólnik może skorzystać ze środków ochrony przewidzianych przez Kodeks handlowy (por. m.in. art. 197 § 1, art. 205, art. 227 $\S 1$, art. 240 k.h.)”.

45 J. Frąckowiak, Glosa do uchwały SN z dnia 9 października 1991 r., III CZP 93/91, „Orzecznictwo Sądów Polskich” 1992, nr 10, poz. 213.

46 A. Jakubecki, w: Kodeks postępowania, komentarz do art. 730', teza 6. Zob. również odpowiednio postanowienie SN z dnia 19 października 1983 r., I CZ 155/83, „Orzecznictwo Sądu Najwyższego Izba Cywilna” 1984, nr 5, poz. 83.

47 T. Ereciński, w: Kodeks postępowania cywilnego. Komentarz. Tom IV. Postępowanie rozpoznawcze. Postępowanie zabezpieczające, red. T. Ereciński, Warszawa 2016, komentarz do art. $730^{1}$, teza 5. 
akcyjnej. Stosownie do art. 268 k.s.h. w sprawach takich w celu zabezpieczenia powództwa sąd może, z ważnych powodów, zawiesić wspólnika w wykonywaniu jego praw udziałowych w spółce. Istnienie ważnych powodów, o których mowa w art. 268 k.s.h., jest przy tym dodatkową, a nie wyłączną przesłanką udzielenia zabezpieczenia powództwa $z$ art. $266 \S 1$ k.s.h. ${ }^{48} \mathrm{~W}$ piśmiennictwie wskazano, że wnosząc wniosek o udzielenie zabezpieczenia na podstawie art. 268 k.s.h., wnioskodawca będzie zmuszony uprawdopodobnić ważne powody (w znaczeniu uprawdopodobnienia roszczenia), a ponadto interes prawny w udzieleniu zabezpieczenia (art. $730^{1}$ $\S 1$ k.p.c.), której to przesłanki nie można już w żadnym razie łączyć ani z ważnymi powodami, ani z uprawdopodobnieniem roszczenia. W konsekwencji zabezpieczenie roszczenia w postaci zawieszenia wspólnika w wykonywaniu jego praw udziałowych w spółce będzie wymagało podstawy nie tylko $z$ art. 268 k.s.h., lecz także $z$ art. $730^{1}$ $\S 1$ k.p.c. ${ }^{49}$

W tym miejscu należy zauważyć, że konsekwencje udzielenia zabezpieczenia są w tym przypadku daleko idące. W zakresie objętym zabezpieczeniem przyjmuje się tak, jakby wspólnika nie było. Oznacza to, że przy ustalaniu quorum wymaganego do podejmowania uchwał przez zgromadzenie wspólników spółki z ograniczoną odpowiedzialnością nie uwzględnia się udziałów wspólnika zawieszonego w wykonywaniu jego praw członkowskich w spółce ${ }^{50}$. Zabezpieczenie wydane na podstawie art. $282 \S 2$ k.s.h. nie tylko stanowi formę tymczasowej ochrony prawnej, o charakterze pewnego prowizorium obowiązującego na czas trwania procesu, ale także wywiera skutki trwałe. Wiążą się one m.in. z tym, że podjęte bez

48 Zob. uzasadnienie postanowienia SA w Krakowie $\mathrm{z}$ dnia 12 listopada 2013 r., I ACz 1880/13, Legalis nr 804476.

${ }^{49}$ Ł. Błaszczak, Zabezpieczenie roszczeń $w$ sporach korporacyjnych na przykładzie spraw o uchylenie lub stwierdzenie nieważności uchwały wspólników oraz spraw o wyłaczenie wspólnika, „Transformacje Prawa Prywatnego” 2019, nr 1 , s. 5 i n.

50 Zob. uzasadnienie postanowienia SN z dnia 26 marca 2002 r., III CKN 1238/99, OSNC 2003 nr 5, poz. 61; uzasadnienie postanowienia SA w Poznaniu z dnia 22 września 2017 r., I ACa 111/17, Legalis nr 1714420. 
udziału zawieszonego w prawach członkowskich wspólnika uchwały pozostają ważne i prawnie skuteczne, choćby zabezpieczone w ten sposób powództwo o jego wyłączenie zostało ostatecznie oddalone ${ }^{51}$.

\section{Podsumowanie}

Celem postępowania zabezpieczającego jest udzielenie natychmiastowej i prowizorycznej, co do zasady, ochrony prawnej określonym podmiotom po to, aby dane postępowanie cywilne, którego przeprowadzenie i ostateczne wymaga czasu, faktycznie osiągnęło swój zamierzony $\mathrm{cel}^{52}$. W postępowaniu w sprawach gospodarczych nabiera ono szczególnego znaczenia, gdyż mimo zakładanej szybkości ich załatwiania brak zabezpieczenia niejednokrotnie zniweczyłby skutki prawomocnego orzeczenia w sprawie, uniemożliwiając lub poważnie utrudniając jego wykonanie. Jest to szczególnie widoczne w sprawach o ukształtowanie prawa lub stosunku prawnego albo ustalenie prawa lub stosunku prawnego.

Specyfiką postępowań w sprawach gospodarczych jest zwłaszcza stosunkowo częste składanie wniosku o udzielenie zabezpieczenia we wspomnianych wyżej sprawach o uchylenie uchwały lub stwierdzenie jej nieważności. Wnioski takie składane są niemal we wszystkich tego typu sprawach. Wiąże się to $z$ faktem, że zaskarżone uchwały $\mathrm{w}$ przypadku nieudzielenia zabezpieczenia często mogą prowadzić do powstania niepowetowanych strat po stronie uprawnionego. W szczególności dotyczy to uchwał, które kształtują sytuację spółki, np. dotyczących podwyższenia kapitału zakładowego (których celem może być „wyciskanie” wspólników mniejszościowych), zmian w składzie rady nadzorczej czy zarządu. Specyfiką spraw gospodarczych jest także to, że orzeczenie w przedmiocie udzielenia zabezpieczenia, niezależnie od tego, czy zabezpieczenie będzie udzielone, czy wniosek będzie oddalony, w sposób istotny

${ }^{51}$ Zob. uzasadnienie postanowienia SA w Poznaniu z dnia 22 września 2017 r., I ACa 111/17, Legalis nr 1714420.

52 D. Rystał, w: Kodeks postępowania, komentarz do art. 730, teza 2. 
wpłynie na obrót gospodarczy, stabilizując pewien stan faktyczny, np. w zakresie zarządzania spółką. Nierzadko odnosi się to do dużych podmiotów, w tym notowanych na rynku giełdowym, na rynkach równoległych lub alternatywnych. Rozpoznając takie wnioski, należy zatem zachować szczególną ostrożność i rozwagę. Co prawda ustawodawca przewiduje wspomnianą odpowiedzialność odszkodowawczą uprawnionego $z$ art. 746 k.p.c., jednak może ona okazać się iluzoryczna w przypadku, gdy uprawniony nie posiada środków na naprawienie szkody. Nie należy zatem wykluczać prowadzenia przez sąd, w ograniczonym zakresie, weryfikacji twierdzeń i dowodów zaoferowanych przez uprawnionego, w szczególności w oparciu o fakty znane sądowi $z$ urzędu $z$ innych postępowań.

Kolejną specyficzną cechą wniosków o udzielenie zabezpieczenia w sprawach gospodarczych jest stosunkowo częste składanie wniosków o udzielenie zabezpieczenia na etapie przedprocesowym. Jak wskazano wyżej, wynika to po części z prób „testowania” sądu przed wytoczeniem powództwa, jakie są szanse wygrania procesu. Jest to szczególnie widoczne w sprawach o roszczenia niepieniężne z uwagi na nadal bardzo niską - jak na sprawy gospodarcze - opłatę sądową (100 zł - art. 68 pkt 1 u.k.s.s.c.).

Stosunkowo rzadziej wnioski o udzielenie zabezpieczenia w sprawach gospodarczych składane są w sprawach o zapłatę. Dotyczyć to będzie głównie przypadków, w których obowiązany od dłuższego czasu nie reguluje swoich długów, prowadzone są postępowania egzekucyjne względem bądź do uprawnionego docierają informacje o wyzbywaniu się przez niego majątku. Sama obawa uprawnionego, że nie uzyska zaspokojenia, jest niewystarczająca do udzielenia zabezpieczenia, a sądy w tych przypadkach są dość rygorystyczne.

Resumując, złożoność i stopień skomplikowania spraw gospodarczych tworzą pole do popisu tak dla orzecznictwa sądowego, jak i dla doktryny. Zawsze przy tym należy mieć na względzie doniosłość tych spraw dla obrotu gospodarczego oraz ekonomiczne skutki orzeczeń w przedmiocie udzielenia zabezpieczenia. 


\title{
STRESZCZENIE
}

\author{
Postępowanie zabezpieczające \\ w sprawach gospodarczych
}

Celem artykułu jest omówienie wybranych instytucji postępowania zabezpieczającego w kontekście specyfiki spraw gospodarczych. Wnioski o udzielenie zabezpieczenia w tego typu sprawach wpływają do sądów dość często, zwłaszcza w sprawach o stwierdzenie nieważności uchwały bądź jej uchylenie. Orzeczenie sądu ma natomiast daleko idące skutki dla obrotu gospodarczego.

Słowa kluczowe: postępowanie zabezpieczające; sprawy gospodarcze

\section{SUMMARY}

Court's proceedings to secure claims in business lawsuits

This article's aim is to discuss selected institutions of proceedings to secure claims in the context of the specific character of business lawsuits. Applications for securing claims in this type of cases are submitted to the courts quite often, especially in cases concerning the declaration of resolution's invalidity or its annulment. On the other hand, the court's ruling has far-reaching consequences for economic transactions.

Keywords: proceedings to secure claims; business lawsuits

\section{BIBLIOGRAFIA}

Bieniak J. (red.), Kodeks spółek handlowych. Komentarz, Warszawa 2020. Błaszczak Ł., Zabezpieczenie roszczeń $w$ sporach korporacyjnych na przykładzie spraw o uchylenie lub stwierdzenie nieważności uchwały wspólników oraz spraw o wyłaczenie wspólnika, „Transformacje Prawa Prywatnego" 2019, nr 1.

Dolecki H., Wiśniewski T. (red.), Kodeks postępowania cywilnego. Komentarz. Tom IV. Artykuty 730-1088, Warszawa 2014. 
Dumkiewicz M., Kidyba A., Wybrane problemy zwiazane ze skutkami zaskarżania uchwał zgromadzeń spółek kapitałowych $w$ przedmiocie podziału zysku, „Przegląd Prawa Handlowego” 2013, nr 11.

Ereciński T. (red.), Kodeks postępowania cywilnego. Komentarz. Tom IV. Postępowanie rozpoznawcze. Postępowanie zabezpieczajace, Warszawa 2016.

Frąckowiak J., Glosa do uchwały SN z dnia 9 października 1991 r., III CZP 93/91, „Orzecznictwo Sądów Polskich” 1992, nr 10, poz. 213.

Jakubecki A. (red.), Kodeks postępowania cywilnego. Komentarz do wybranych przepisów nowelizacji 2019, Warszawa 2019.

Jankowski J. (red.), Kodeks postępowania cywilnego. Tom II. Komentarz do art. 730-1217, Warszawa 2019.

Jara Z. (red.), Kodeks spółek handlowych. Komentarz, Warszawa 2020.

Lewandowski M., Glosa do orzeczenia SN z dnia 24 lutego 1999 r., III CKN 182/98, „Problemy Egzekucji” 2000, nr 4.

Manowska M. (red.), Kodeks postępowania cywilnego. Komentarz. Tom II. Art. 478-1217, Warszawa 2021.

Marciniak A. (red.), Kodeks postępowania cywilnego. Tom IV. Komentarz. Art. 730-1095 ${ }^{1}$, Warszawa 2021.

Owczarewicz A., Zabezpieczenie powództwa o uchylenie bądź stwierdzenie nieważności uchwał organów właścicielskich spółek kapitałowych przez zawieszenie postępowania rejestrowego po nowelizacji Kodeksu postępowania cywilnego, „Prawo Spółek” 2012, nr 11-12.

Regucki T., Czy sprzeczność ze statutem albo umowa spółki może być samodzielną podstawą powództwa o uchylenie uchwały?, „Przegląd Prawa Handlowego" 2014, nr 10.

Stefańska E., Odpowiedzialność cywilnoprawna za szkodę wyrzadzona wykonaniem zabezpieczenia, „Transformacje Prawa Prywatnego” 2019, nr 1.

Szanciło T. (red.), Kodeks postępowania cywilnego. Tom II. Komentarz do art. 506-1217, Warszawa 2020.

Szumański A. (red.), Prawo spółek handlowych. System Prawa Handlowego. Tom 2A, Warszawa 2019. 